\title{
The International Law Commission and the International Law Codification Market
}

\author{
Zuzana Trávníčková
}

\section{Introduction}

There must be hundreds of university teachers of international law around the world, and I am one of them. I am teaching students at the University of Economics in Prague. Some of them head into national or international business or media, some become diplomats, others start their career at a ministry of foreign affairs or in international institutions. My aim is to introduce them to international law, visualize and explain the mechanisms of creation and application of international rules and principles, as well as of peaceful settlement of disputes, and also to provide them with some orientation among the many institutions in the "international law universe". My students, on the other hand, bring into our discussions in lectures and seminars their fresh, young look at different international legal topics and confront me with their knowledge from other courses. Compared to students pursuing a law degree, our students have a blurrier awareness of how legislation and the law work. In their deliberations about current international events, they are not restricted by such knowledge and that is why their arguments and views may be sometimes naïve and sometimes inspiring. I was thinking about my students often when I was preparing this presentation and I am very grateful for all the opinions and ideas about international law that they were willing to "trade" with me and that ultimately led me to the idea of the international law codification market.

Let me introduce this market, identify trends concerning it and formulate a few predictions. Further, this contribution will touch on other questions (e.g. the composition of the International Law Commission) discussed during the celebration of the Commission's seventieth anniversary event in Geneva in July 2018.

Building bridges between economics and international law is not a new idea. However, economic issues seem to be more attractive for international lawyers than international law as a subject of study for economists. Whereas 
international economic law represents a developed and established field of public international law, there are only few attempts to apply economic perspectives to international law. Alan O. Sykes, ${ }^{1}$ Andrew Guzman ${ }^{2}$ and Eric A. Posner ${ }^{3}$ can be mentioned as leading authors providing economic analysis of international law. Jeffrey L. Dunoff and Joel P. Trachtman present an analogy between the market of international relations and the traditional markets for goods. ${ }^{4}$ The aim of the following text is to contribute to this discussion by applying simplified market theory to the codification of international law.

\section{The International Law Codification Market}

Markets may be differentiated by many criteria: by geographic extension of the market, intensity of speculation, legality of exchange, volatility of the market or by products or factors sold. Codification of international law is not a good, but it could be understood as a service. It is a very special service, it demands deeply specialized knowledge and it has a very special clientele. Clients are paying not with money, but with recognition of the International Law Commission's legitimacy and respect. There is no free and fully competitive market of international law codification, but it is some kind of market, because there is an international law codification demand and - on the other side - the international law codification supply. The following text focuses on three characteristics of the market: on the codification of international law as the service offered, on the International Law Commission as the leading supplier and on States as demanders.

\section{Codification as a Service on the Market}

In this contribution, codification is discussed as a service and understood in a simplified way as the preparation of draft conventions. There is one fundamental question that must discussed before we approach the virtual codification

1 Alan O Sykes, 'The Economics of Public International Law' (2004) John M. Olin Program in Law and Economics Working Paper No. 216 <https://pdfs.semanticscholar.org/d48b/dff047413c0485d876a5f6e67cb52276od67.pdf>.

2 Andrew Guzman and Alan O Sykes, 'Economics of International Law' in Francesco Parisi (ed), The Oxford Handbook of Law and Economics (oup 2017).

3 Eric A Posner (ed), Economics of Public International Law (Elgar 2010).

4 Jeffrey L Dunoff and Joel P Trachtman, 'Economic Analysis of International Law' (2004) 24(1) YaleJIntlL 1. 
market where draft articles for possible future conventions are offered. Is the codification of international law a type of service that can be "sold and bought" or is it a service comparable to a public good? Pure public goods are not traded in markets, because they are supplied to the community as a whole and without direct charge being paid for the good. This is why the (profit-oriented) private sector is not willing to produce and supply them. The production and allocation of public goods is not determined by the market but by the political process. ${ }^{5}$ Public goods create market failures because they cannot be allocated by the market mechanism. If codification is a public good, then it is useless to construct any market for it.

There are different ways to distinguish between private and public goods, mainly by testing the excludability/non-excludability and rivalry/non-rivalry of consumers and the possibility of consumers to reject/avoid the good. ${ }^{6}$ Pure public goods are non-excludable and non-rivalrous, and their consumption is non-rejectable. ${ }^{7}$ Regular examples of public goods include lighthouses, street lighting, flood control system or national defence. Academic literature has made different efforts to classify law, ${ }^{8}$ natural law, ${ }^{9}$ international law, ${ }^{10}$ the international law "liability" system, ${ }^{11}$ enforcement of international environmental agreements, ${ }^{12}$ and law enforcement in the penal system ${ }^{13}$ or in general ${ }^{14}$ as

$5 \quad$ Vicky Allsopp, Understanding Economics (Routledge 2006) 129.

6 Ibid. See also Yew-Kwang Ng, Welfare Economics: Towards a More Complete Analysis (Palgrave Macmillan 2004) 165 .

7 Finn R Førsund, 'Allocation in Space and Environmental Pollution' (1972) The Swedish Journal of Economics 19; Clara S Haignere, 'Closing the Ecological Gap: the Public/Private Dilemma' (1999) 4(14) Health Education Research 507; Stephen J Bailey, Public Sector Economics: Theory, Policy and Practice (Macmillan International Higher Education 1995) 30. Tyler Cowen, 'Law as a Public Good: The Economics of Anarchy' (1992) 8(2) Economics and Philosophy 249; David D Friedman, 'Law as a Private Good: A Response to Tyler Cowen on the Economics of Anarchy' (1994) 10(2) Economics and Philosophy 319.

9 Peter Wivel, 'The State and The Citizen Natural Law as a Public Good' in Erik A Andersen and Birgit Lindsnaes (eds), Towards New Global Strategies: Public Goods and Human Rights (Martinus Nijhoff 2007) 3 .

Thomas Gammeltoft-Hansen, 'Does International Refugee Law Still Matter?' (2016) Migration and Citizenship: "Newsletter of the American Political Science Association: Organized Section on Migration and Citizenship < connect.apsanet.org/s43/ wp-content/uploads/sites/13/2017/o6/APSACitizenshipMigrationNewsletter_42_final. pdf>.

11 Dunoff and Trachtman (n 24) 26.

12 Tseming Yang, 'International Treaty Enforcement as a Public Good: Institutional Deterrent Sanctions in International Environmental Agreements' (2006) 27 MichJIntlL 1131.

13 Randall Kennedy, 'The State, Criminal Law, and Racial Discrimination: A Comment' (1993) 107 HarvLRev 1255.

14 Mark Gradstein, ‘Governance and growth' (2004) 73(2) JDevEcon 55, 518. 
a public or a common good; however, the overall conclusions are ambiguous. But even if we had conclusive knowledge of the public/private nature of the law as a good, we could not apply it to codification of law as such.

When we look at the codification of international law as a service offered to States, we can test its characteristics in the light of excludability, rivalry and rejectability. As was said already, the drafting of conventions is a very special service. For purposes of this contribution, codification is understood in the wider sense of the term and covers both activities defined in article 16 of the statute of the International Law Commission, ${ }^{15}$ i.e. not only the "more precise formulation and systematization of rules of international law"16 but also as their progressive development.

The international community's efforts to codify international rules started in the 19th century ${ }^{17}$ and are today embodied in Article 13, paragraph 1, of the Charter of the United Nations. The provision entrusts the General Assembly with initiating studies and making recommendations for the purpose of "promoting international co-operation in the political field and encouraging the progressive development of international law and its codification". Since the codification of international law is geared towards international co-operation, it fulfils the economic condition of non-excludability. Codification as a service is non-excludable by its very nature. With regard to the second condition of a public good, the non-rivalry of States in relation to codification drafts is obvious, States are regularly invited and called upon to sign, ratify or accede to multilateral international treaties (especially during the Treaty Events organized by the Secretary-General of the United Nations since 2001), regardless of whether their representatives participated in the preparation of the draft articles for those treaties.

Nevertheless, testing the third characteristic of public goods - nonrejectability - leads to the conclusion that the codification of international law is not a pure public good, because States - as consumers - may reject/ avoid the offered product. In practice, we typically do not witness the direct or open rejection of the International Law Commission's outcomes; however States express their different views regarding the draft articles produced by the Commission in the Sixth Committee of the General Assembly. Moreover,

15 Statute of the ILC, UNGA Res 174(II) (21 November 1947) as amended by UNGA Res 485(v) (12 December 1950); Unga Res 984(x) (3 December 1955); Unga Res 985(x) (3 December 1955) and UNGA Res 36/39 (18 November 1981).

16 Ibid article 15.

17 On the history of the codification movement, see keynote address by Nico Schrijver in Section 8 of this volume. 
States may adopt the draft articles in the form of a treaty, they may sign and ratify or accede to the treaty, or they may choose to do none of the above. Due to their sovereignty, States cannot be forced and are not obliged to accept draft articles prepared by the International Law Commission or other institutions. The Vienna Convention on the Representation of States in their Relations with International Organizations of a Universal Character ${ }^{18}$ which was adopted in 1975 and is still not in force, may be mentioned as an example of avoiding the outcome of the Commission's codification effort. Codification of international law as a service is non-excludable and not-rivalrous, but it can be rejected; then it can be concluded, that as a non-public good, the codification can be studied as a service supplied and demanded on the market.

Looking more closely at the market, several forms of output of the codification service may be identified. The most visible ones are drafts of multilateral conventions prepared by the International Law Commission (article 20 of its statute). Ideally, these drafts are accepted by the General Assembly and/or States, adopted in the form of a treaty which is widely ratified by States. The Commission may also complete its work on a topic (e.g. State responsibility for internationally wrongful acts in $2001,{ }^{19}$ or status of the diplomatic courier and the diplomatic bag not accompanied by the diplomatic courier in 1989) ${ }^{20}$ and submit it to the General Assembly, without the adoption of a binding treaty. Other forms of outcomes include declarations, resolutions and model laws. ${ }^{21}$ In addition, final or interim reports elaborated by a Special Rapporteur, a working or a study group represent an important outcome of the Commission, although it must be added that those products are not mainly used by States (as the leading demanders) but by international judicial institutions and scholars.

Since 2000 (exactly, when the topic "Fragmentation of international law: difficulties arising from the diversification and expansion of international law" was included in the Commission's long-term programme of work $)^{22}$ an inside-driven development in the methods of work at the Commission can be

18 Adopted 14 March 1975, not yet in force, UN Doc A/CONF.67/16.

19 ILC, 'Draft articles on responsibility of States for internationally wrongful acts' [2001] II(2) ILC Ybk 26.

$20 \quad$ ILC, 'Draft articles on the status of the diplomatic courier and the diplomatic bag not accompanied by diplomatic courier and draft optional protocols thereto' [1989] II(2) ILC Ybk14.

21 Pemmaraju Sreenivasa Rao, 'International Law Commission (ILC)' Max Planck Encyclopedia of Public International Law (March 2017) <opil.ouplaw.com/home/EPIL>, para 27.

22 ILC, 'Report of the International Law Commission on the work of its fifty-second session' [2000] II (2) ILC Ybk 1, 131 at para 729. 
observed. ${ }^{23} \mathrm{~A}$ new approach ${ }^{24}$ emerged to topics that are of significant theoretical or practical importance - but not suitable for codification in international conventions, such as "Fragmentation of international law", "Peremptory norms of general international law (jus cogens)" or "Identification of customary international law". These topics go beyond the narrow mandate of preparing a draft treaty. These topics may be difficult for States to handle because their representatives tend to be more practical and problem-oriented. Lawyers working at ministries of foreign affairs would probably not have the time to study the historical background and theoretical aspects of the problem and might also be constrained by the foreign policy of their government. By preparing outcomes other than a draft treaty, the International Law Commission has thus found a new and innovative product to offer.

\section{v The International Law Commission as the Supplier of Codification}

The International Law Commission can be perceived as one of the main and the leading suppliers of international law codification. It is difficult to imagine what international law would look like without the International Law Commission. Of course, States have a lot of negotiating capacity and could have devoted it to the law of treaties, to diplomatic and consular law, to the succession of states and other topics, but would they have done so? Shortly after the International Law Commission was established in the late 1940s, the air in the international community was filled with political and ideological tensions. In the 1950s, political and economic relations between the two blocs of power were frozen or openly hostile. But still, there was a demand for treaties, expressed by States especially since the end of the First World War and not fully satisfied by the League of Nations and the Committee of Experts for the Progressive Codification of International Law. The Commission as a supplier was very active, worked hard on crucial legal topics and prepared several drafts of very successful (measured by the number of State parties) treaties in the

23 For a discussion of the Commission's methods of work, see the contributions in Section 4 of this volume.

24 The report of the International Law Commission in 2000 mentions only two previous Commission efforts (reservations to multilateral treaties in 1950 and participation of new States in certain general multilateral treaties in 1962, concluded under the auspices of the League of Nations), when the ILC was working on a topic with a plan to present a study, without an ambition to present draft articles as a basis for a future international convention. ILC (n 22) 149 . 
195os and 196os. The Vienna Conventions on Diplomatic Relations of $1961,{ }^{25}$ on Consular Relations of $1963^{26}$ and on the Law of Treaties, adopted by States in $1969,{ }^{27}$ are the brightest examples.

Later, when relations in the international community became more constructive, the ability of States to co-operate did not replace the need for a professional and specialized codification body. Besides, the International Law Commission had demonstrated that codification through a specialized legal organ is not only possible, but also effective. The failure of the League of Nations codification efforts had been overcome. The International Law Commission's position in the market became firm, undisputable, and also unique.

Why is the International Law Commission unique? The first answer is its authority. First of all, the Commission has formal authority based on the way it was created and the Commission's position in the United Nations system. The members of the International Law Commission are elected by the General Assembly, the Commission's reports are regularly discussed in the Sixth (Legal) Committee of the General Assembly, and in Switzerland, members of the Commission enjoy the privileges and immunities to which the judges of the International Court of Justice and the heads of missions accredited to international organizations in Geneva are entitled. ${ }^{28}$ But besides this formal authority, there is also another form of authority that may be called "professional authority" and that is not bestowed but must be earned. Although not every draft prepared by the International Law Commission is subsequently transformed into a treaty, the list of conventions based on the International Law Commission drafts is still very impressive.

The second answer is the composition of the International Law Commission. Article 2 of the Commission's statute requires that the members of the Commission are persons of recognized competence in international law and that they must be nationals of different States. According to article 8, the composition of the Commission as an organ should represent the main forms of civilization and of the principal legal systems of the world, and a defined number of seats is assigned to each of the regional groups. ${ }^{29}$ When my students look at the picture of Commission members on the Commission's website, the first thing they notice is the disproportion between the number of women and

\footnotetext{
25 Adopted 18 April 1961, entered into force 24 April 1964, 500 UNTS 95.

26 Adopted 24 April 1963, entered into force 19 March 1967, 596 UNTS 261.

27 Adopted 23 May 1969, entered into force 27 January 1980, 1155 UNTS 331.

28 ILC, 'Report of the Commission to the General Assembly on the work of its thirty-first Session' [1979] II (2) ILC Ybk 1, 8 at para 12. 
men. They express their disapproval and say that "it is not fair" to have more male than female members. We then read articles 2, 8 and 9 of the Commission's statute together and discuss the election process for members of the Commission. We discuss who is "responsible" for the small number of women in the International Law Commission. It is neither the Commission itself nor is it the statute. Candidates are nominated by States and elected by the General Assembly (except for cases of casual vacancies under article 11 of the statute). Our partial conclusion usually is that amending the statute to introduce a quota for women would not be helpful. And there is a question hidden behind this reasoning. Is it wrong, or is it a real problem, that there are less women than men? It would be wrong if women were excluded from membership. It would be a problem, when the feminine attitude to international law would be something else than the masculine one and as a result, the small number of women would influence the quality of commission outcomes. However, my students and I are not able to answer those hidden questions. So we usually conclude that knowledge of and attitude towards international law are a matter of expertise and experience and not a matter of gender, and that the natural development in this question does not require any formal interference.

There is one more argument supporting the strength of the International Law Commission in the codification process: the Commission's capacity to deal with international affairs comprehensively, to provide a wide range of services. The agenda of the Commission since its inception has been very colourful, and its members enjoy quite interesting (of course not unlimited) freedom to propose new topics. The Commission may not only provide different forms of outcomes (drafts of multilateral treaties, reports, studies), but also, from the material point of view, it may focus on any topic that relates to public (and theoretically private) international law.

Does that mean that there is no competition in the market of codification of international law and that the International Law Commission has the monopoly? Definitively not. As Sir Arthur Watts stated, the International Law Commission "is not the exclusive vehicle for the codification and progressive development of international law". ${ }^{30}$ Watts further gives a list of other codification endeavours that includes the General Assembly, conferences convened by the United Nations, the United Nations Commission on International Trade Law (UnCITRAL), the Human Rights Committee, the International Committee of the Red Cross, the Organization for Economic Co-operation and Development

$30 \quad$ Arthur Watts, 'Codification and Progressive Development of International Law', Max Planck Encyclopedia of Public International Law (December 20o6) <opil.ouplaw.com/ home/EPIL >, para 23 . 
(OECD), the Hague Conference on Private International Law and academic institutions such as the International Law Association or Institute for the Unification of Private Law (UNIDROIT). ${ }^{31}$ The codification of international law is thus carried out by many institutions, which can be classified by their scope of operation (their specialization on public or private international law, international trade law, international economic law or human rights), on the one hand, and by their "distance" from States, on the other hand.

Although this codification environment looks very competitive, in fact the general or specialized focus of every supplier ensures sufficient space for operation for all of them. In the advisory opinion on Reparation for Injuries Suffered in the Service of the United Nations, the International Court of Justice argued that " $[t]$ he subjects of law in any legal system are not necessarily identical in their nature or in the extent of their rights, and their nature depends upon the needs of the community". ${ }^{2}$ The establishment of the International Law Commission, the United Nations Commission on International Trade Law and other intergovernmental codification institutions was in every case motivated by the concrete and topical need of the international community to cover a smaller or bigger part of the codification demand. On the one hand, the finding that States as demanders (at least partially) determine the group of suppliers is definitely contrary to the rules of the free market and challenges the argument made in this contribution; on the other hand, it confirms that there is no natural competition between actors participating in the codification of international law.

In a model market, several variables influence suppliers: the price of a good/ service, input prices, technology, expectations and the number of sellers. The number of suppliers and input prices play no role for sellers on the international law codification market. Assessment of the influence of technology on the Commission's activity is beyond the focus of this contribution. The price of a service is not expressed in money, but in the legitimacy of the International Law Commission. In the short-term, the price - legitimacy - does not matter. But in the long-term, the Commission must be sure to obtain and retain enough legitimacy for its existence and activities. Measuring the legitimacy of political institutions and international institutions is an attractive challenge for scholars in political studies; ${ }^{33}$ however, this contribution does not

$31 \quad$ Ibid paras $23-26$.

32 Reparation for Injuries Suffered in the Service of the United Nations (Advisory Opinion) [1949] ICJ Rep 174, 178.

33

Tetsuo Sato, 'Legitimacy of International Organizations and their Decisions: Challenges that International Organizations Face in the $21^{\text {st }}$ Century' (2009) 37 Hitotsubashi Journal of Law and Politics 11; Mark C Suchman, 'Managing Legitimacy: Strategic and Institutional 
apply any of the proposed models (based mainly on comparative qualitativequantitative analysis) and approaches legitimacy more generally.

Legitimacy as a belief in the International Law Commission can be understood as depending on the workload of the Commission. Whether the International Law Commission identifies topics for codification by itself (and obtains the General Assembly's approval), or it receives special assignments by the General Assembly, which should be given priority according to article 18, paragraph 3, of the Commission's statute, in both situations the demand confirms the legitimacy of the Commission. The legitimacy is closely linked to expectations (on the side of supply as well as on the side of demand). Suppliers' expectations are expressed by the reports of the Commission's Planning Group, and States voice their expectations by accepting the Commission's programme of work.

\section{States as the Main Demanders of Codification}

Codification in the wider sense covers both aims contained in article 15 of the Commission's statute, "the preparation of draft conventions on subjects which have not yet been regulated by international law or in regard to which the law has not yet been sufficiently developed in the practice of States" as well as "the more precise formulation and systematization of rules of international law in fields where there already has been extensive State practice, precedent and doctrine". The terms "conventions", "States" and "State practice" used in the quotations above illustrate the crucial role of States in the creation of international law. Other provisions of the statute support the position of States as influential demanders; e.g. article 21, paragraph 2 grants them possibility to comment on International Law Commission's drafts and article 23 enables the General Assembly (an organ composed of States representatives) to refer drafts back to the Commission for reconsideration or redrafting.

There are also other actors interested in products of the codification of international law, namely international courts and tribunals, domestic courts, other codification bodies, legal advisers of international organizations, and the academy. However, their buying power and demand seems to be quite weak in comparison to States and it is more accurate to speak of them as consumers rather than demanders.

Approaches' (1995) 20(3) Academy of Management Review 571; Ian Hurd, 'Legitimacy and Authority in International Politics' (1999) 53(2) International Organization Journal 379. 
The International Law Commission, as a subsidiary organ of the General Assembly, presents its work to the General Assembly, which means to all Member States of the United Nations. According to article 23, paragraph 1, of its statute, the Commission may recommend to the General Assembly to take note of or adopt the Commission's report by resolution, recommend a draft for adoption as a convention, or suggest the convening of a diplomatic conference for that purpose. ${ }^{34}$ However, the verb "recommend" used in the introductory sentence of article 23 expresses clearly the position of the International Law Commission in relation to the General Assembly and Member States of the United Nations. By submitting the final draft with commentaries (according to article 22 of the Commission's statute), the work of the International Law Commission is completed and the future of the draft lies in the hands of General Assembly and Member States.

The International Law Commission studies topics and prepares draft articles, States adopt them as or use them as a basis to negotiate treaties. States obtain and use draft articles as the final product of the Commission's work. The fact that States do not act unilaterally, but use a multilateral channel - the General Assembly and its Sixth Committee - does not weaken the importance of States as actors in international legislation. It is sovereign States that nominate candidates, elect the members of the International Law Commission, may influence, through their comments and observations, the contents of the Commission's reports and decide the fate of the Commission's outcomes. The relationship between the International Law Commission and States respects the universal logic of international law as a set of rules created by States as the only holders of normative power. Of course, the influence of other actors should not be omitted, but in the field of general international law, it is not as visible as in human rights, humanitarian law or environmental protection.

Demanders on the ideal market make their decisions under the influence of many factors. They consider the price of goods/services, their income, prices of related goods/services, tastes, expectations and the overall number of buyers. $^{35}$ The international law codification market is not a market of that kind. Prices and income do not matter here, and the number of buyers is not important, because they are not competing for codification as a scarce service draft articles are available for every State. "Tastes" and "expectations" are the main factors determining the demand for the codification of international law. Tastes and expectations may play such an important role because of the

\footnotetext{
34 It may, however, also recommend " $[\mathrm{t}] \mathrm{o}$ take no action, the report having already been published".

See e.g. Hugh Stretton, Economics: A New Introduction (Pluto Press 200o) 259-263.
} 
sovereignty of States. Codification takes some time and during that time the tastes and expectations of consumers may change. The law of special missions might serve as an example, especially when we compare this topic with diplomatic relations. In 196o, the General Assembly agreed to codify the law of ad hoc missions together with the law of permanent diplomatic missions at a diplomatic conference in Vienna. ${ }^{36}$ This idea was later rejected, and the Vienna Convention on Diplomatic Relations was adopted in 1961 and entered into force in $1964 .{ }^{37}$ The work on special missions was completed by the International Law Commission in $1966 .{ }^{38}$ In 1969, the General Assembly adopted the Convention on Special Missions ${ }^{39}$ and in June 1985 , more than 15 years later, the Convention entered into force. ${ }^{40}$ The fact that tastes and expectation of States regarding the codification of the law of ad hoc missions changed in time, is illustrated not only by the number of years between adoption and entry into force of both treaties, but also by the number of State parties (191 States had joined the Vienna Convention on Diplomatic Relations, 39 States ratified or acceded to the Convention on Special Missions by September 2018).

On the Commission's website, an overview called "Periods during which topics were on the agenda of the International Law Commission" can be found.$^{41}$ It presents not only the wide scope of topics covered from 1949, but also illustrates the dynamics of the Commission's work. Through this table, the changes and perhaps also difficulties on the market can be identified. A shift can be observed from "big topics" crowned by "big conventions" to more specialized particular issues, on the one hand, and to theoretical problems and general questions, on the other hand. Moreover, the average time devoted to a topic has increased. Excluding the very special topic of "State responsibility for internationally wrongful acts" and limiting the attention to completed topics only, the Commission has worked for an average of 4.9 years on topics opened between 1949 to 1959 and for 8.5 years on topics opened between 1996 and 2006.

The topic of State responsibility appeared on the agenda six times and took 41 years (1954, 1956-1961, 1963, 1967 and 1969-2001) to complete. From a

36 UNGa Res 1504 (xv) (12 December 1960).

37 Adopted 18 April 1961, entered into force 24 April 1964, 50o UNTS 95.

38 ILC, 'Draft articles on special missions, with commentaries' [1967] II ILC Ybk 347.

39 UNGA Res 2530 (xxIv) (8 December 1969).

40 Convention on Special Missions, adopted 8 December 1969, entered into force 21 June 1985, 1400 UNTS 231.

41 ILC, 'Periods during which topics were on the Agenda of the Commission' <http://legal. un.org/ilc/guide/annexı.shtml>. 
marketing perspective, it was very difficult to introduce the product, that is the articles on responsibility of States for internationally wrongful acts of $2001 .{ }^{42}$ The product concept was changed substantially over time, several responsible "product managers" (i.e. Special Rapporteurs) were in charge, and the demand and the tastes and expectations of demanders were not easy to identify and understand. In 1988, Philip Allott opened his article on "Unmaking of International Law" with the following statement:

The Commission's work [on State responsibility] raises fundamental questions not only about the state of contemporary international law but also about the existence and functioning of the Commission itself. There is reason to believe that the Commission's long and laborious work on state responsibility is doing serious long-term damage to international law and international society. ${ }^{43}$

A profit-oriented business would probably give up such a project after a few years and devote its attention to a product with better prospects. The International Law Commission has the possibility to discontinue a topic (as it happened to privileges and immunities of international organizations in 1992), ${ }^{44}$ but it decided to complete the challenging task. In the model market, the failure of the product endangers the reputation of the producer. Sometimes, buyers are tolerant and forgive a failure, but in the long-term they repudiate those who do not fulfil their expectations. In the international codification market, dropping a topic is perceived as failure.

In 2001, the articles on responsibility of States for internationally wrongful acts were launched on the market. It is not easy to find an appropriate adjective to characterize the reaction of the demand side to this launch. Maybe the word "half-hearted" describes most accurately the fact that the General Assembly "welcomed the conclusion of the work of the International Law Commission on responsibility of States for internationally wrongful acts and its adoption of the draft articles and a detailed commentary on the subject"45 and decided to revisit it on a triennial basis.

\footnotetext{
$42 \quad$ ILC (n 19).

43 Philip Allott, 'State Responsibility and the Unmaking of International Law' (1988) 29 HarvIntlLJ 1.

44 ILC, 'Report of the International Law Commission on the work of its forty-fourth session' [1992] II (2) ILC Ybk 1, 53 at para 362. 


\section{The International Law Codification Market in the Future}

As indicated above, the international law codification market is far from a perfect market, because suppliers and demanders are not two independent groups of actors, and States on the demanding side may influence and govern the activity of suppliers or create new suppliers. During the manufacturing of the product, they may carry out continuous control, from beginning to end. The application of the model market to the codification of international law is also deficient in many other aspects. Nevertheless, the market and marketing optics is useful to explain important processes surrounding the International Law Commission. Particularly in situations when States obtain draft articles as a product of the Commission's work and consider the further procedure (buying and using or rejecting), they act like demanders on a market. They weigh their expectations and tastes before they react.

What are the possibilities and the pitfalls for the Commission in the decade to come? From the economic perspective, we should consider ongoing and predictable changes on the side of demand, on the side of supply and in the market environment. The behaviour of demanders changes slowly but steadily, while the aggregate demand for codification weakens. States as clients examine each of the Commission's products carefully before they accept it and they can express their disapproval. They also can satisfy their demand on their own and conclude treaties at summits and other meetings. On the side of suppliers, the International Law Commission still holds a unique position; other suppliers currently offer, and will in the close future presumably remain limited to, highly specialized products on human rights, humanitarian law and international trade law. Regarding the market environment, other actors on the market - regional and national courts - should be considered. However, their role is ambiguous: they do not sell and buy, but they use the final outcomes of the International Law Commission and, at the same time, they influence the content of products of the International Law Commission.

Regarding the future production of the International Law Commission, the term "international law" as it is contained in the name of the Commission may be the key challenge. The statute of the Commission states in article 1, paragraph 2: "The Commission shall concern itself primarily with public international law, but is not precluded from entering the field of private international law." The drafters of the document were probably thinking about public international law as a set of rules governing the relations between States and also some aspects of relations with intergovernmental organizations and they also had a clear vision of what constitutes private international law. Their vision of 
international law is captured in contemporary literature ${ }^{46}$ and also in the list of topics suggested for codification in $1949 .{ }^{47}$

However, human society and the international community have changed since 1947. Processes like globalization, humanization, constitutionalization, democratization and regionalization influence society and influence the law. They blur the boundaries between public and private international law, regional law and national law. They introduce terms like global law or transnational law to the discussion. Finding out what are fashionable terms and what are real trends in the international community and thinking about international interstate law in the context of other binding normative systems may be one of the future market possibilities for the International Law Commission.

46 International law definitions were discussed e.g. by Alfred von Verdross, 'On the Concept of International Law' (1949) 43(3) AJIL 435.

47 ILC, 'Survey of International Law in Relation to the Work of Codification of the International Law Commission: Preparatory work within the purview of article 18, paragraph 1, of the of the International Law Commission - Memorandum submitted by the Secretary-General' (1o February 1949) UN Doc A/CN.4/1/Rev.1. 